\title{
Evolution of management of local development processes (on the example of Bagrationovsky district of the Kaliningrad region)
}

\author{
Andrey Gorokhov ${ }^{1, *}$, Alexey Ignatyev ${ }^{2}$, Vitaly Smirnov ${ }^{3}$ \\ ${ }^{1}$ Moscow state University of technology and management. K. G. Razumovsky, Zemlyanoy Val street, \\ 73, Moscow, 109004, Russia \\ ${ }^{2}$ The non-profit organization "Regional Economic Development Agency", Dmitry Donskoy street 1, \\ Kaliningrad, 236007, Russia \\ ${ }^{3}$ Moscow Aviation Institute, Volokolamskoe highway, 4, Moscow, 125993, Russia
}

\begin{abstract}
The purpose of the study is to develop a potential mechanism for monitoring and motivating municipal authorities, based on the evolution of management of development processes. The paper describes the positive experience of management of local development processes on the example of the Bagrationovsky urban settlement, whose administration actively interacted with the pharmaceutical company "Infamed-K" located in Bagrationovsk. As a result, it was possible not only to ensure the participation of the settlement in various regional and federal programs on co-financing terms, fully pay off the past due debt that has occurred earlier, but also create a favorable living environment and solve many problems of the residents.
\end{abstract}

\section{Introduction}

In 2011 and 2014 The Agency for Regional Economic Development, in conjunction with the government of the Kaliningrad region, conducted studies on the implementation of the functions of local sustainable development by municipal formations (MFs) of different levels [1,2]

One of the conclusions of the study was the statement of inefficient use by the MFs administrations of their potential, and also their weak interest in establishing partnership (balanced) [3] relations with investors and entrepreneurs working on their territory.

However, in two settlements: the Bagrationovsky urban settlement of Bagrationovsky district and the Svobodnensky rural settlement (RS), the administration actively interacted with the pharmaceutical company OJSC "Infamed-K". This company is located in Bagrationovsk. It is one of the flagships of the modern Russian pharmacological industry. In 2014 it launched its new production of the universal antiseptic "Miramistin", which has no analogues in the world.

\footnotetext{
${ }^{*}$ Corresponding author: andgorokhov@gmail.com
} 


\section{Materials and methods}

Aware of the responsibility not only for the success of its enterprise, but also for creating a comfortable living environment throughout the urban settlement, the founders of the OJSC "Infamed-K" decided to register in Bagrationovsk and pay taxes on income and dividends to shareholders there. This allowed to significantly increase the own income of the settlement (Table 1).

Table 1. Income of financial resources to the budget of Bagrationovsk, million rubles.

\begin{tabular}{|c|l|c|c|c|c|}
\hline № & \multicolumn{1}{|c|}{ Name } & \multicolumn{1}{|c|}{2013} & 2014 & 2015 & 2016 \\
\hline 1 & \multicolumn{1}{|c|}{2} & 3 & 4 & 5 & 6 \\
\hline 1 & Own income & 24.425 & 34.706 & 57.698 & 55.600 \\
\hline 2. & $\begin{array}{l}\text { Additional resources for the } \\
\text { development of the city from } \\
\text { the district and regional budgets }\end{array}$ & & 3.400 & 26.085 & 33.454 \\
\hline 3. & Personal Income Tax (PIT) & 12.367 & 15.391 & 40.721 & 38.796 \\
\hline 4 & Land tax & 3.277 & 5.553 & 8.688 & 7.998 \\
\hline 5 & Dotations & 7.198 & 1.662 & 10.400 & 0.471 \\
\hline 6 & Subsidies & 86.864 & 59.206 & 41.145 & 29.006 \\
\hline 7 & Other interbudgetary transfers & 4.021 & 3.844 & 15.272 & 4.860 \\
\hline 8 & Total & 122.508 & 99.418 & 124.515 & 89.937 \\
\hline
\end{tabular}

At the same time, in order to ensure control and effective use of budgetary resources, the founders and top management of the company became members of the Council of the Bagrationovsky urban settlement by the result of elections held in 2013.

The active position of the deputy corps of the Bagrationovsky urban settlement made it possible not only to effectively use own budget of the settlement, but also to attract additional resources for the development of the city from the district and regional budgets within the limits of the coming share of PIT - founders of "Infamed-K" (Table 1).

At the same time, the total volume of budget expenses of the settlement for the period from 2015 to 2016 has not significantly changed; the share of budget expenses of the settlement in relation to the total amount of the budget has gradually decreased (Table 2).

Table 2. Dynamics of the expenditure budget.

\begin{tabular}{|l|c|c|c|c|}
\hline \multicolumn{1}{|c|}{ Bagrationovsky US } & 2013 & 2014 & 2015 & 2016 \\
\hline Expenditure budget, million rubles & 115.698 & 101.057 & 124.516 & 88.714 \\
\hline Share of budget expenses, \% & 43 & 42 & 41 & 41 \\
\hline
\end{tabular}

Due to a sharp increase in the revenues of financial resources to the budget of Bagrationovsk through the growth of PIT, the administration of the MF managed not only to ensure the participation of the settlement in various programs, but also to fully pay off the past due debt occurred in 2012-2013 (Table 3).

Table 3. Expenses for the implementation of programs, million rubles.

\begin{tabular}{|l|c|c|l|l|}
\hline \multicolumn{1}{|c|}{ Bagrationovsky US } & 2013 & 2014 & 2015 & 2016 \\
\hline $\begin{array}{l}\text { Expenses for the implementation of } \\
\text { programs, total }\end{array}$ & 50.646 & 42.454 & 51.396 & 33.866 \\
\hline $\begin{array}{l}\text { Expenses for the implementation of } \\
\text { federal programs }\end{array}$ & 30.639 & 39.868 & - & - \\
\hline Budget expenses of the settlement & 34.403 & 18.735 & 73.120 & 54.848 \\
\hline
\end{tabular}

In the period from 2014 to 2017, the administration of the Bagrationovsky urban settlement began to actively participate in the implementation of various state and municipal programs, including the improvement program [4], the "Specific cases" program 
[5] of major repairs of apartment buildings, resettlement of citizens from unfit housing stock, production waste handling, and also FTP (Federal Targeted Programme) [6] and the Regional Investment Program (RIP) [7].

The total number of programs in Bagrationovsk in which the settlement took part increased from 3 in 2013 to 5 in 2017.

In the implementation of the "Specific cases" programs due to support from the local budget, the sidewalks were repaired, street lighting was equipped, container platforms for collection of solid household waste (SHW) were installed, children's playgrounds were installed, lamps were changed for energy saving ones, and other activities were held in the city in the period from 2014 to 2017.

Over the last few years, 27 houses have been overhauled on the territory of the Bagrationovsky urban settlement (Table 4).

Table 4. Participation in the program of major repairs of apartment buildings.

\begin{tabular}{|l|c|c|c|c|}
\hline \multicolumn{1}{|c|}{ Bagrationovsky US } & 2013 & 2014 & 2015 & 2016 \\
\hline Number of renovated houses, units & 3 & 7 & 13 & 4 \\
\hline Amount of financing, thousand rubles. & 1937 & 7991 & 20339 & 1717 \\
\hline
\end{tabular}

Due to the active development of housing construction, it was possible to reduce the number of persons on a waiting list from 119 people (2013) to 72 (end of 2017).

The Public Council began to work. The public and entrepreneurs are involved in the discussion and development of documents related to the municipal formation: strategic planning, master plan and territory planning, and also in the monitoring of their implementation [8].

Now the advanced experience of Bagrationovsk is adopted by the Bagrationovsky urban district. A similar public structure has already been created there and is beginning to work.

The joint well-coordinated work of the administration and the City Council, with the support of the Government of the Kaliningrad region, made it possible to implement projects that ensure the sustainable social and economic development of Bagrationovsk for the long term.

In the period from 2014 to 2017, the design and estimate documentation for a number of socially significant facilities was developed, which is an indispensable prerequisite for their inclusion in regional and federal development programs.

Therefore, as a result of almost five years of operation, the Municipal Administration managed to make the settlement attractive to investment and, as a result, to significantly increase the level of revenues of the municipal budget, and also to take part into various development programs, thereby ensuring real changes in the formation of a favourable living environment and solving the problems of residents of Bagrationovsk.

Similar successes were achieved in the Svobodnensky rural settlement of the Chernyakhov district.

The interaction of municipal authorities and local business involves active work of both sides. But only the desire of the entrepreneur to invest in the municipality, create jobs and pay taxes is not enough. The municipality must ensure the countermotion by correctly disposing the resources that the business community offers. And this means a new quality of work of the local administration. First, the administration should not "bronze in bureaucratic arrogance". It should become open, allowing the business community to participate in decision-making on a consultative basis. Eventually, the legal right of the entrepreneur is to know what his taxes, which form the local budget, have gone into. Whether the landscaping, gasification, major repairs, etc. are implemented on their basis. Whether the budget is spent rationally, spending is targeted and is beneficial to residents, many of whom are employees of local businesses or members of their families. The welfare of employees, the absence of domestic problems is an important factor for any responsible 
entrepreneur who builds a business "for a long time" and thinks for a decade ahead. All in all, it gives personnel stability in the enterprise and good labor productivity. The employee can concentrate on work; his head is not stuffed up by a leaking roof of the house or lack of places in the kindergarten for children. This need of entrepreneurs should be taken into account by the local administration while building relationships with the business community.

The increase in the municipal budget is a new opportunity to implement development programs in the territory. But at the same time, it is a significant increase in the workload for the administration staff. It is necessary to work more, more actively, more efficiently, which increases the responsibility and creates a special mission of the municipal authority.

However, if the administration would fail to reach a new level of management, sooner or later other people will come to take its place. This happened in the Bagrationovsky urban district where voters chose a different government in the elections last year. The former membership was not able to cope with the work under new conditions. People came to the polls and voted for those who will cope.

\section{Results}

As a result of the work, proposals were made to replicate the successful experience of the Bagrationovsky MF in other municipalities in the Kaliningrad region.

1. It is necessary to develop a rating of investment attractiveness of municipalities in the region in accordance with the model of the investment rating of the federal subjects, which is made by the Russian Agency for Strategic Initiatives.

For the regional leadership, the investment rating represents a potential mechanism for monitoring and motivating the municipal authorities. As a result, the governor will be able to assess the work of the local leadership. This experience exists in Krasnodar Krai. Today, this region is the leader in the rating of investment attractiveness.

2. The creation of an advanced management model will require new managerial competencies, retraining of municipal personnel.

3. Modernization of the management system of municipalities on the basis of understandable performance criteria, for example - KPI, which are incorporated into the concept of the Development Strategy of the Kaliningrad region.

4. The setting of specific tasks and the development of specific projects should be carried out on the basis of strategic goals, since the Kaliningrad exclave should have unique preferences among other regions of the country.

\section{Discussions}

On the basis of the gained experience of the positive interaction of entrepreneurs and local authorities in the Bagrationovsky urban settlement of the Kaliningrad region in the interests of local development, following recommendations were formulated:

1. Administrations of the MFs should actively work to create a favorable investment and business climate, which is the main condition for the emergence of new enterprises and taxpayers, who form the local budget, in the MF. Particular attention should be paid to the motivation for resettlement in the MF of large entrepreneurs willing to pay Personal Income Tax and a tax on dividends at their place of registration;

2. The work of administration of the MF needs to be reformed through the maximum possible introduction of project principles, an objective assessment of the work of managers and executors, risk assessment, effective use of existing and attracted resources for project implementation. To implement the most important projects for the community, it is 
advisable to create a project team (office, agency) from among the personnel prepared for this work;

3. It is advisable to establish cooperation with district and regional authorities in order to make maximum use of their development resources through the available program tools of the federal, regional and international (cross-border cooperation) level;

4. It is also advisable to use more actively the experience of project management of municipal development processes in the neighboring border areas of Poland for the implementation of a coordinated development project for border municipalities (for example, Bagrationovsky urban district and Bartoszycki district) in order to obtain synergies and more efficient use of available resources.

\section{Conclusion}

1. The analyzed cases are inherently the best practices of local development and can be used as models in other municipalities of the Kaliningrad region and the country in general. 2. They demonstrate how it is possible to create a management system for development processes in the partnership mode between socially responsible business and municipal authorities, and not only to form a new resource package, but also to use it effectively for the benefit of local communities.

3. Taking into account the general trend aimed at the liquidation of settlements and the reform of the districts in the urban districts in order to increase the efficiency of the administrations of the MFs of the second level and the first-level MFs included in it, and also to reduce the costs for the administrative apparatus, it is advisable to abandon the twolevel management system and concentrate resources, powers and responsibility on administrations and councils of deputies of a district level.

4. In this regard, in 2018 it is expected to develop and implement the "Effective Municipality" model based on the proposed recommendations in one of the city districts of the Kaliningrad region.

\section{References}

1. V.N. Ivanova, A.Y. Gorohov, A.Y. Ignatev, A.A. Ignateva, V.G. Smirnov, Ekonomicheskie nauki 4(125), 94-99 (2016)

2. A.Y. Gorohov, D.A, Gorohov A.Y. Ignatev, V.G. Smirnov, Ekonomicheskie nauki 11, 64-72 (2016)

3. A. Jones, G. Fallon, R. Golov, European Business Review 12(4), 187-197, doi. 10.1108/09555340010336871

4. I.V. Ilin, A.I. Levina, O.Yu. Iliashenko, MATEC Web of Conf. 86, 05028 (2016) doi: 10.1051/matecconf/20168605028

5. A. Ilin, O. Kalinina, O. Iliashenko, A. Levina, Procedia Engineering 165, 1673- 1682 (2016) doi: 10.1016/j.proeng.2016.11.909

6. A. Zaychenko, S. Gutman, O. Kalinina, Advances in Intelligent Systems and Computing 692, 453-462 (2018) doi: 10.1007/978-3-319-70987-1_48

7. A. Borboni, F. Aggogeri, A. Merlo, N. Pellegrini, C. Amici, International Journal of Advanced Robotic Systems 12, 42 (2015) DOI: 10.5772/60052

8. V. Pukhkal, V. Murgul, M. Garifullin, Procedia Engineering 117, 624-627 (2015) 